\title{
JOURNAL.RU
}

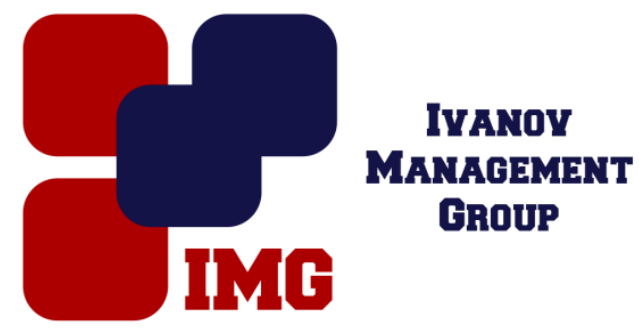

Кондратьев Д.М.

Российский университет дружбы народов Москва, Россия

doi: 10.18411/lj-30-06-2017-29

idsp 000001:1j-30-06-2017-29

\section{Анализ судебной практики по рассмотрению споров, возникших в сфере аренды земель сельскохозяйственного назначения}

\section{Аннотация}

В рамках представленной статьи проанализирована судебная практика по рассмотрению споров, возникших в сфере аренды земель сельскохозяйственного назначения.

Ключевые слова: сельскохозяйственное назначение, аренда, земля, назначение, споры.

\section{Abstract}

Within the framework of the presented article the judicial practice on consideration of the disputes, arisen in the sphere of lease of agricultural land, was analyzed.

Keywords: agricultural purpose, lease, land, purpose, disputes.

В настоящее время судами в РФ рассматривается до $2 \%$ исков от общего количества, которые связаны с вопросами землепользования. В последние годы большая часть претензий была связана с межевыми границами и оборотом земель сельскохозяйственного назначения, то сегодня ситуация изменилась. Большая часть дел, рассматриваемых в суде сегодня, касается вопросов ограничения землепользования и ведения кадастрового учета. На основании ст. 30 ГПК РФ все споры, возникшие в результате землепользования, подлежат рассмотрению по месту нахождения объекта. Большая часть дел в сфере аренды 
земель сельскохозяйственного назначения рассматривается районными судами. В то же время некоторые дела рассматриваются мировыми судами (споры о порядке землепользования, за исключением тех дел, которые связаны с выставлением иных претензий). Согласно ст. 23 ГПК РФ, мировыми судами рассматриваются иски, которые касаются земель с кадастровой стоимостью, не превышающей 50 тыс. руб.

В муниципальной и государственной собственности находится большая часть сельскохозяйственных земель. Претендуя на возможность заключения договора аренды, предприниматели и физические лица обращаются с документами для оформления земельных участков в аренду. Не все чиновники выносят положительное решение относительно аренды, поэтому граждане и предприниматели обжалуют действия (или бездействие) должностных лиц в судебном порядке. Специфика рассмотрения данной категории дел заключается в том, что участок может быть предоставлен в аренду с заключением договора в порядке, который предусматривает ст. 445 ГК РФ. 24 глава АПК предусматривает, что для устранения допущенного нарушения должностному лицу требуется подготовить проект договора и отправить его для ознакомления заявителю.

29 ст. Земельного кодекса РФ предусматривает, что земли сельскохозяйственного назначения, которые принадлежат муниципалитетам, могут быть переданы в аренду с заключением договора и подготовкой соответствующего решения администрации. 11 ст. Земельного кодекса РФ предусматривает, что вопросы управления и распоряжения земельными участками муниципалитеты решают самостоятельно при условии нахождения на балансе муниципальной собственности. В случае если судом признается недействительность решения об отказе в предоставлении участка в аренду, администрацию муниципалитета обязывают подготовить проект договора для заявителя.

Предприниматель (дело А-291-7040/08) обратился в суд с обжалованием отказа в предоставлении земельного участка в аренду для ведения сельскохозяйственной деятельности. На основании ст. 31-32 Земельного кодекса РФ и ст. 610 и 621 ГК РФ судом было вынесено решение об удовлетворении требований истца (предоставление участка в пользование и заключение договора аренды). В качестве обоснования своего решения суд привел следующие доводы: земельный участок был поставлен в установленном порядке на кадастровый учет и передан на баланс муниципалитета. Имея право 
распоряжения земельными участками в своей собственности, муниципалитет опубликовал в местной газете объявление о сдаче в аренду земельного участка, предназначенного для ведения сельскохозяйственной деятельности. Таким образом, в районном суде были полностью удовлетворены требования истца, и земельный участок был передан в аренду в установленном порядке.

Частное лицо (дело А-18-312/10) обратилось в суд с требованием признать недействительным решение о застройке земельного участка, ранее переданного в аренду для ведения сельскохозяйственной деятельности. Суд, изучив материалы дела, пришел к выводу о том, что с истцом был заключен договор аренды земли для ведения сельскохозяйственной деятельности сроком на 5 лет. Спустя год после заключения договора, (когда срок его действия еще не истек), администрация муниципалитета утвердила генеральный план застройки заречной части города и включила арендованный участок в план застройки. При этом арендатор не был уведомлен об изменении категории землепользования и обратился в администрацию с требованием подтвердить действительность намерений администрации о застройке. Получив отказ от дальнейшего исполнения обязанностей по договору от муниципалитета, истец обратился в суд и потребовал исключить земельный участок из плана застройки и право на аренду земельного участка. Суд, принимая решение, взял во внимание п.П. 6, 8 ст. 31, ст. 32 Земельного кодекса РФ и постановил: признать право землепользования за истцом и обязать администрацию муниципалитета при подготовке плана застройки учитывать границы ранее переданных в аренду земельных участков.

По делу А-61-8064/14 был принят к производству иск о взыскании задолженности по аренде земельного участка, предназначенного для ведения сельскохозяйственной деятельности. Суд, изучая материалы дела, установил, что между физическим лицом и администрацией муниципалитета был заключен договор аренды земельного участка сроком на 3 года. Через год с момента подписания договора, администрация в одностороннем порядке потребовала погашения задолженности по арендной плате. Как выяснилось, физическое лицо исправно платило плату за аренду, однако администрация в одностороннем порядке изменила методику расчета платы за аренду и потребовала с арендатора вернуть долг по арендной плате. Ст. 424 ГК РФ и ст. 65 Земельного кодекса РФ позволили суду прийти к выводу о том, что цена аренды может быть регулируемой, однако не может быть изменена в одностороннем порядке. Ранее указанные положения в договоре о размере арендной платы были признаны 
актуальными. Таким образом, иск по арендной плате со стороны муниципалитета был отклонен. Апелляционный суд согласился с выводами первой инстанции и подтвердил действительность ранее вынесенного судебного решения.

По делу А-17-3207/15 администрация поселка Солнечное обратилась в суд с требованием взыскать сумму долга за фактическое пользование землей, предназначенной для ведения сельскохозяйственной деятельности. В судебном заседании были изучены доводы сторон, в качестве ответчика выступил руководитель кооператива, который без договора аренды пользовался земельным участком, который принадлежал муниципалитету. В подтверждение доводов администрация привела акт проверки землепользования, которым было подтверждено, что указанный земельный участок использовался для осуществления сельскохозяйственной деятельности. Положения ст. 65 Земельного кодекса РФ, и ст. 424, 1105 ГК РФ позволили суду рассматривать использование земельного участка для ведения деятельности в качестве отношений землепользования, которые привели к незаконному обогащению. О необоснованном обогащении суд сделал вывод по результатам изучения решения Ленинградской областной думы о сумме арендной платы за земельные участки, передаваемые во временное пользование (аренду) физическим лицам и предпринимателям. Суд постановил взыскать платежи за использование участка, исходя из фактического срока землепользования и тарифов, принятых решением областной думы.

$* * *$

1. Барсукова Г.Н. Трансакционные издержки при оформлении прав собственности на земельные участки / Г.Н. Барсукова, В.В. Нечаев, К. А. Юрченко // АПК: экономика, управление. - 2012. - № 7. - С. 30-37.

2. Горемыкин В. А. Недвижимость: экономика, управление, налогооблажение, учет: учебник. - М.: КНОРУС, 2013. - 672 с.

3. Ермакова Е.П., Ситкарева Е.В. Право Европейского Союза: порядок разрешения частноправовых споров. - Учебное пособие. - М., Юрлитинформ, 2016, (17,5 п.л.) С..115. 